Alzaghrini N., Srour F.J., and Srour I. (2017). "Using optimization to manage quarries in the recycling of construction and demolition waste." In: LC3 2017: Volume I - Proceedings of the Joint Conference on Computing in Construction (JC3), July 4-7, 2017, Heraklion, Greece, pp. 541-551. DOI: https://doi.org/10.24928/JC3-2017/0151.

\title{
USING OPTIMIZATION TO MANAGE QUARRIES IN THE RECYCLING OF CONSTRUCTION AND DEMOLITION WASTE
}

\author{
Nadine AlZaghrini ${ }^{1}$, Issam Srour ${ }^{2}$, and F. Jordan Srour ${ }^{3}$
}

\begin{abstract}
The construction industry consumes large amounts of aggregates, sand, and stone causing a strain on the limited sources of these natural materials (i.e., quarries). The industry is also a major source of waste. Waste, commonly referred to as Construction and Demolition Waste (C\&DW), is generated at various stages of construction and in demolition processes. Increased construction activities and limited landfill space have encouraged efforts to divert C\&DW away from landfills to sorting, recycling, and reusing. While these efforts have been successful in some countries (e.g., Germany, Netherlands), developing countries such as Lebanon suffer from illegal and haphazard dumping of C\&DW. This paper reports on an ongoing research project which investigates synergies between two elements of the construction industry, C\&DW and quarries. The aim is to develop an optimization model that will provide decision support in the selection of a cost and environmentally effective set of abandoned quarries to serve as C\&DW landfills, as and processing facilities.
\end{abstract}

Keywords: Construction and demolition waste, sustainability, recycling network, waste management, optimization.

\section{INTRODUCTION}

The impact of construction activities is twofold, boosting the economy on one hand, while burdening the environment on the other. In the Middle East, where $\$ 2.8$ trillion worth of projects are being planned or executed in the Gulf Cooperation Council (GCC) countries alone, the stress on natural resources will only continue to grow (Deloitte \& Touche (M.E.), 2015). On average, the building of one apartment requires 200-300 tons of aggregates and one $\mathrm{km}$ of road or highway requires 5,000 and 20,000 tons respectively (MOE/UNDP/ECODIT, 2011).

As a result of construction activities, different types of waste are generated in the different phases of a project's lifecycle. Soil, rocks and vegetation result from excavation and land levelling. Inert materials, such as concrete, tiles, bricks and steel, result during construction and demolition. Wood, plastic, and metals result from the finishing phase. Construction and demolition waste (C\&DW) in particular can result either from nonemergency states (demolition by consent or need) or from emergency states (act of God, wars, etc.). The large volumes in which these wastes are generated pose a considerable

1 Graduate Student, Dept. of Civil and Environmental Engineering, American University of Beirut, Beirut, Lebanon, nadine.alzaghrini@gmail.com

2 Associate Professor, Dept. of Civil and Environmental Engineering, American University of Beirut, Beirut, Lebanon, issam.srour@aub.edu.lb

3 Assistant Professor, Dept. of IT and Operations Management, Lebanese American University, Beirut, Lebanon, jordan.srour@lau.edu.lb 
threat to the environment and thus require a solution. Despite the high-recycling potentials of C\&DW permitting reuse rates exceeding 80\% in Germany, Denmark and Netherlands (Eurostat 2015), scarce efforts are being implemented in under-developed countries. Barriers to sorting and processing C\&DW are either industry specific or organizational: Construction projects are characterized with long life spans, entailing thus different owners with different attitudes towards recycling. Also, these projects must be designed for deconstruction, each treated uniquely for its specific risks (Hosseini et al. 2015). Other barriers include the absence of processing facilities with adequate capacities, the lack of legal and economic incentives as well as appropriate monitoring (Srour et al. 2013). Consequently, management of C\&DW is a challenge for cities and countries with high population density and limited landfill capacity (e.g., Beirut, Lebanon). An appealing approach consists in restoring abandoned quarries into C\&DW recycling facilities. However, several physical constraints such as stability, settlement and hydrological conditions must be carefully considered in order to minimize additional environmental damage.

The objective of this paper is to explore the synergies between two elements of the construction industry: quarries and C\&DW. The specific aim is to lay the foundation for an optimization based model to match potential recycling facility sites (e.g. abandoned quarries) to sources of C\&DW while minimizing the carbon footprint and monetary cost of transportation to the facilities, management of the recycling facilities, and transportation of recycled materials back to corresponding markets.

\section{LITERATURE REVIEW}

This section explains the recent methods adopted for C\&DW quantification as well as the benefits of using recycled over conventional concrete. Also, previous optimization models used for waste management are reviewed.

\subsection{Categorization and Quantification of C\&DW}

Three major categories of waste can be found during the different construction stages from shoring to finishing. These include inert (rocks, soil, concrete, masonry, tiles, etc.), non-inert (metals, wood, paper, cardboard, etc.) and hazardous materials (corrosive, explosive or flammable) (Malia et al. 2013).

Proper management of C\&DW begins with determining the quantities being produced (Martínez Lage et al. 2010). The quantification of C\&DW provides vital input to various parameters such as location and the size of landfills and processing facilities, as well as legislations required to encourage and enforce proper management of C\&DW (Srour et al. 2013). Different methods have been explored in the literature accounting mainly for the level of difficulty to access statistical data, and the sources of the C\&DW. Table 1 presents a sample of studies focusing on the estimation of inert C\&DW.

\subsection{Recycled versus Conventional Concrete}

Facing the considerable environmental damage, proper waste management is of essence. Sorting and processing refuse not only reduces the stress on raw materials, the emissions of $\mathrm{CO} 2$ due to a decrease in energy consumption needed for production, and 
Table 1: Estimation methods for non-emergency C\&DW

\begin{tabular}{|c|c|c|c|}
\hline Type & Reference & Description & Results \\
\hline \multirow{5}{*}{ 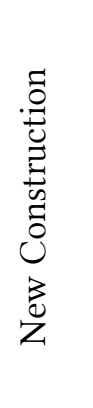 } & \multirow[t]{5}{*}{$\begin{array}{l}\text { Bakshan et al. } \\
\text { (2015) }\end{array}$} & \multirow{2}{*}{$\begin{array}{l}\text {-Provides a methodology to } \\
\text { estimate waste generation rates } \\
\text { (WGR) for each major type of } \\
\text { major materials. }\end{array}$} & $\begin{aligned} \text { WGR }= & 38-43 \mathrm{~kg} / \mathrm{m} 2 \text { of built- } \\
& \text { up area (BA) }\end{aligned}$ \\
\hline & & & $\begin{array}{l}\text { For a } 10 \% \text { WGR from } \\
\text { unaccounted streams: }\end{array}$ \\
\hline & & \multirow{3}{*}{$\begin{array}{l}\text {-Data collected from several } \\
\text { projects, WGR computed and } \\
\text { compared to values obtained in } \\
\text { literature in order to validate the } \\
\text { method. }\end{array}$} & WGR CONCRETE $=23 \%$ \\
\hline & & & WGR MASONRY $=46.1 \%$ \\
\hline & & & WGR TILES $=5.3 \%$ \\
\hline \multirow{13}{*}{ 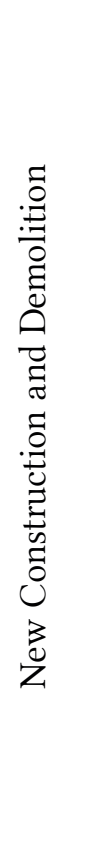 } & $\begin{array}{l}\text { BRE } \\
\text { SMARTWaste } \\
(2008)\end{array}$ & $\begin{array}{l}\text { - Monitoring and reporting tool: } \\
\text { manages resource use and } \\
\text { reduces waste generation. }\end{array}$ & \multirow[t]{4}{*}{ Case Specific Results } \\
\hline & Developed by & - The Pre-demolition Audit & \\
\hline & British Research & Module maximizes resource & \\
\hline & $\begin{array}{l}\text { Establishment } \\
\text { (BRE) }\end{array}$ & $\begin{array}{l}\text { reuse and recycle during } \\
\text { demolition phase. }\end{array}$ & \\
\hline & \multirow[t]{9}{*}{ Mália et al. (2013) } & \multirow{5}{*}{$\begin{array}{l}\text { - Data collected from extensive } \\
\text { surveys of international studies, } \\
\text { indicators were determined to } \\
\text { estimate the C\&DW generated } \\
\text { on site by waste stream and } \\
\text { globally. }\end{array}$} & New Residential: \\
\hline & & & $\mathrm{WGR}=17.8-32.9 \mathrm{~kg} / \mathrm{m} 2 \mathrm{BA}$ \\
\hline & & & $\underline{\text { New Non-Residential: }}$ \\
\hline & & & $\mathrm{WGR}=18.3-40.1 \mathrm{~kg} / \mathrm{m} 2 \mathrm{BA}$ \\
\hline & & & $\underline{\text { Residential Demolition RC }}$ \\
\hline & & \multirow{4}{*}{$\begin{array}{l}\text {-Degree of confidence assigned } \\
\text { to the indicators to account for } \\
\text { building characteristics (number } \\
\text { of storeys, type of foundations, } \\
\text { structure and roof). }\end{array}$} & Structures: \\
\hline & & & $\mathrm{WGR}=492-840 \mathrm{~kg} / \mathrm{m} 2 \mathrm{BA}$ \\
\hline & & & $\frac{\text { Non-Residential Demolition }}{\text { R }}$ \\
\hline & & & $\mathrm{WGR}=401-768 \mathrm{~kg} / \mathrm{m} 2 \mathrm{BA}$ \\
\hline \multirow{4}{*}{ 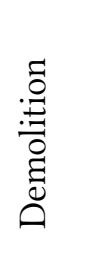 } & \multirow[t]{4}{*}{ Srour et al. (2013) } & \multirow{4}{*}{$\begin{array}{l}\text { - Estimates quantities of } \\
\text { demolition waste based on the } \\
\text { demolition licenses issued per } \\
\text { year, average built-up area and } \\
\text { typical DW density. }\end{array}$} & $\begin{array}{l}\text { For Lebanon in } 2010 \text { in } \\
\text { tons/year: }\end{array}$ \\
\hline & & & $\mathrm{Q}($ concrete $)=528,000$ \\
\hline & & & $\widetilde{\mathrm{Q}}($ masonry $)=186,000$ \\
\hline & & & $\mathrm{Q}($ tiles $)=25,500$ \\
\hline
\end{tabular}

the generation of waste, but it also leads to improved economic and social circumstances. Cost savings are induced by the decreased use of material, energy and the reduced need for waste disposal. Additionally, revenues are earned when selling recovered items. Furthermore, new jobs are created, and improved living conditions are established due to the lower visual and sound pollution (Hosseini et al. 2015).

Recent studies (e.g. Foneca et al. 2011; Knoeri et al. 2013) focused on comparing the environmental benefits of using different recycled concrete (RC) mixtures versus conventional concrete (CC). In terms of the global warming effect, the two options are similar. The larger grain surface area acquired by the use of recycled aggregates necessitates additional quantities of water and cement, a main contributor to global warming (Foneca et al. 2011). In contrast, RC has positive impacts only when coproducts such as recovered steel scrap and avoided transportation and waste disposal 
shifts are accounted for. In this case, RC causes approximately $30 \%$ less damage in terms of preservation of natural resources and diminution of both respiratory inorganics' effects and fossil fuel consumption (Knoeri et al. 2013). It is essential to note that inadequate facility locations and long transportation distances can flip the balance. For this reason, this work seeks to design an optimization model to determine the number, location, and capacities of the different facilities needed to properly manage C\&DW.

\subsection{Waste Management Chain Planning and Modelling}

The process of recycling C\&DW could be compared to the concept of reverse logistics. Figure 1 explains how reverse logistics close the previously linear sequential relationship from design to construction to demolition.

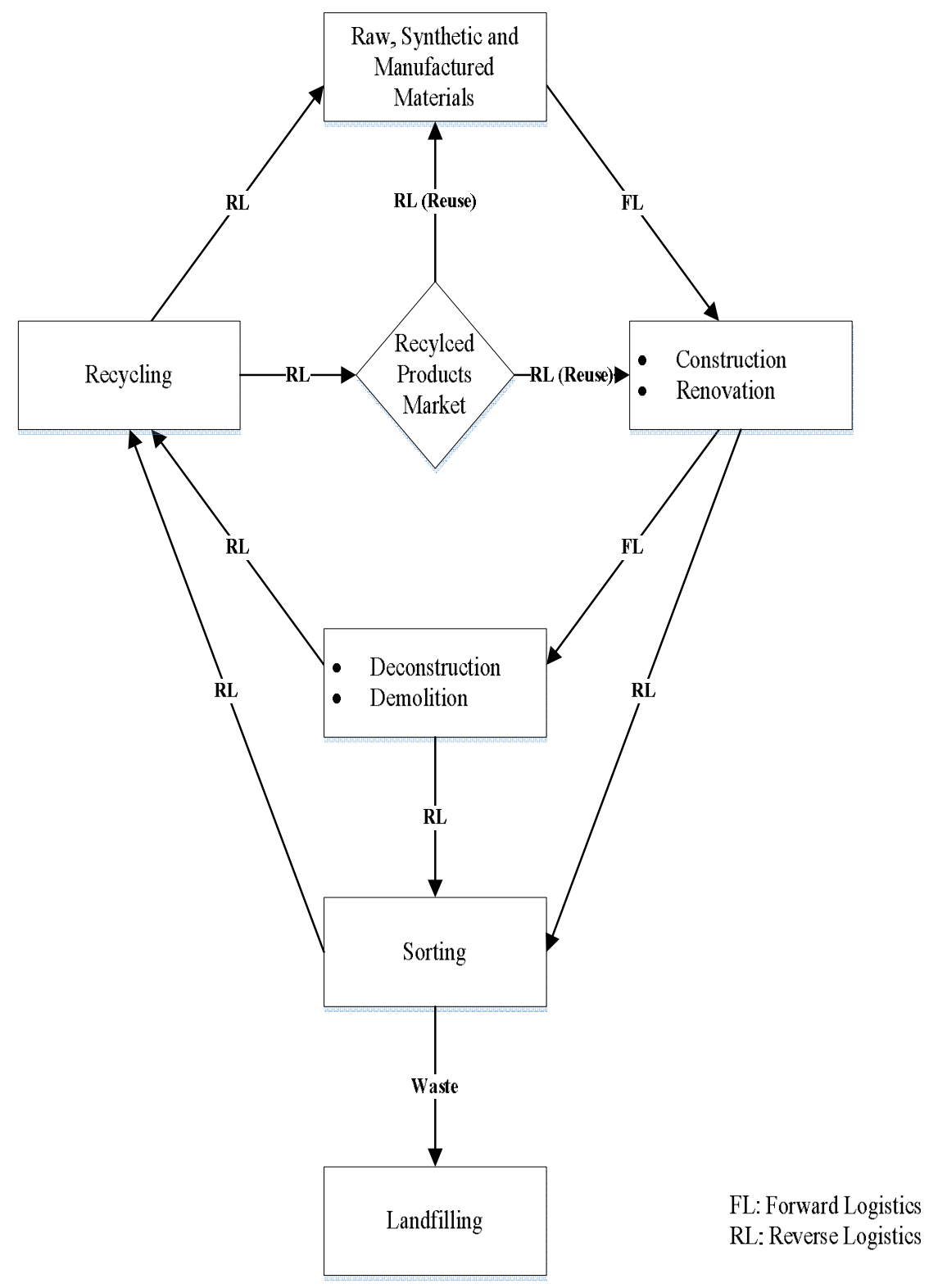

Figure 1: A RL procedure for construction (adapted from Hosseini et al. 2015) 
Numerous models (e.g. Abou Najm et al.2002; Noche et al. 2010; Xi et al.2010) were formulated to improve municipal solid waste management through a common structure accounting for supply, processing and demand. Different technologies for waste handling such as incineration, biological and thermal treatment, composting and landfilling were considered. While the majority of these models focused on network optimization and waste flow, Noche et al. (2010) incorporated plant location planning in their work.

In contrast, modelling the complete C\&DW management chain from the supply of refuse to its handling to the recycled aggregates market demand is rarely addressed in the literature. Srour et al. established a framework for the proper handling of construction demolition waste. Consequently, critical parameters for the economical viability of such process were determined. These include land prices, gate fees and recycled aggregate selling price. Several studies (summarized in Table 2) provided decision-making tools to evaluate adequate locations for processing facilities.

Geographic Information System (GIS) is one of the techniques adopted for this purpose. Robinson and Kapo (2004) extracted specific regional features from the GIS data such as transportation networks, population density, quarries and existing recycling facilities' locations. These identified structures were then used to delineate potential areas in which to locate processing facilities. In parallel, Madi (2016) includes in her GIS analysis slopes, snow and vegetation indices, green and urban areas, buffer distances to water bodies as well as proximity to restricted and allowable roads in order to locate optimal areas to build processing facilities. Contrary to model-driven analysis, this data driven work ignores the implications of transportation costs or the variation of production costs and products value by material type.

An alternative technique adopted is the Mutlicriteria Analysis using ELECTRE III (ELimination and Choice Expressing REality) principles. Depending on the problem addressed, the nature of the recommendation of this approach varies between choosing, ranking and sorting. For the case study applied on Greece, Litochoro scored exceptionally high with respect to the chosen criteria (Banias et al., 2010). This can be attributed to the location of the proposed facility in an abandoned quarry, which supports the objective of the study in progress.

Other authors resorted to integer-linear programming to find the optimal network configuration through cost minimization. Hiete et al. (2010) took account of the both supply and demand as well as the following management options: landfilling and four different recycling techniques leading to different products. The environmental impacts considered are emissions, energy demand and resource consumption. In contrast, Galan et al. (2013) did not account for demand due to high difficulties in the estimation of the end user market, however included transferring stations and adopted two objective functions to respectively minimize financial and environmental costs. 
Table 2: Models used to optimize C\&D network configuration

\begin{tabular}{|c|c|c|c|}
\hline Method & Reference & Explanation & Limitations \\
\hline $\begin{array}{c}\text { GIS Analysis : } \\
\text { Weights of Evidence } \\
\text { (WofE) and } \\
\text { Weighted Logistic } \\
\text { Regression (WLR) } \\
\text { methods }\end{array}$ & $\begin{array}{c}\text { Robinson } \\
\text { and Kapo } \\
(2004)\end{array}$ & $\begin{array}{l}\text { - WofE finds and optimizes spatial } \\
\text { associations between map patterns } \\
\text { and recycling facilities. } \\
\text { - WLR ranks location based on } \\
\text { their suitability through calculated } \\
\text { probabilities. }\end{array}$ & $\begin{array}{c}\text { - Site specific } \\
\text { analysis is needed. } \\
\text { - Missing data and } \\
\text { variance of weights } \\
\text { leads to uncertainty } \\
\text { in results. }\end{array}$ \\
\hline $\begin{array}{l}\text { GIS - MCE } \\
\text { (Multiple-Criterion } \\
\text { Evaluation) } \\
\text { combined with fuzzy } \\
\text { set analysis }\end{array}$ & $\begin{array}{l}\text { Madi } \\
(2016)\end{array}$ & $\begin{array}{l}\text { - Fuzzy logic assigns an influence } \\
\text { factor for each criterion adopted. } \\
\text { - Fuzzy overlay tools (AND, OR, } \\
\text { Equal Weight) define suitability of } \\
\text { a location with respect to } \\
\text { objectives. } \\
\text { - Spatial Analyst Tools assigns } \\
\text { different weights to each objective } \\
\text { and generates final results. }\end{array}$ & $\begin{array}{l}\text { - Results obtained are } \\
\text { area specific; further } \\
\text { site specific analysis } \\
\text { is needed. } \\
\text { - Assumptions may } \\
\text { be required for the } \\
\text { midpoints in the } \\
\text { fuzzy set analysis in } \\
\text { case of lack of proper } \\
\text { legislations. }\end{array}$ \\
\hline $\begin{array}{l}\text { Multicriteria analysis } \\
\text { (MCA) }\end{array}$ & $\begin{array}{l}\text { Banias et } \\
\text { al. }(2010)\end{array}$ & $\begin{array}{l}\text {-Multicriteria evaluation problem } \\
\text { that ranks alternatives based on } \\
\text { their suitability following } \\
\text { ELECTRE III principles. The } \\
\text { decision criteria can be qualitative } \\
\text { or quantitative, and are defined } \\
\text { with respect to environmental and } \\
\text { economical viability as well as } \\
\text { social acceptance. } \\
\text { - LAMSADE software used for the } \\
\text { application of the ELECTRE III } \\
\text { multicriteria analysis. }\end{array}$ & $\begin{array}{l}\text { - Criteria considered } \\
\text { are decision-maker } \\
\text { dependent. } \\
\text { - Thresholds assigned } \\
\text { to each criterion } \\
\text { (indifference versus } \\
\text { strict preferences) are } \\
\text { "notably subjective". } \\
\text { - Sensitivity analysis } \\
\text { required to validate } \\
\text { appropriateness of } \\
\text { results. }\end{array}$ \\
\hline $\begin{array}{l}\text { Mixed-Integer Linear } \\
\text { Programming }\end{array}$ & $\begin{array}{l}\text { Hiete et al. } \\
\quad(2011)\end{array}$ & $\begin{array}{l}\text { - The objective function includes } \\
\text { transportation costs, fixed and } \\
\text { variable processing costs, landfills' } \\
\text { gate fees along with recycled } \\
\text { products' revenues. } \\
\text { - Constraints ensure mainly mass } \\
\text { flow balance as well as the capacity } \\
\text { limitations for different facilities } \\
\text { and forbid the construction of two } \\
\text { identical facilities in the same } \\
\text { location. } \\
\text { - Model implemented in the } \\
\text { General Algebraic Modeling } \\
\text { System (GAMS). }\end{array}$ & $\begin{array}{l}\text { - Dynamic aspect of } \\
\text { the construction } \\
\text { cycle is ignored. } \\
\text { - Stakeholder's profit } \\
\text { maximization is } \\
\text { disregarded. } \\
\text { - Four types of } \\
\text { recycling plants are } \\
\text { only considered. } \\
\text { - Extending existing } \\
\text { facilities is excluded. } \\
\text { and neglecting } \\
\text { mobile plants. }\end{array}$ \\
\hline & $\begin{array}{l}\text { Galan et } \\
\text { al. (2013) }\end{array}$ & $\begin{array}{l}\text { - Two objective functions (OF) } \\
\text { established: }\end{array}$ & $\begin{array}{l}\text { - End-users demand } \\
\text { and location are }\end{array}$ \\
\hline
\end{tabular}


OF1 aims at minimizing transport, installation and treatment costs.

OF2 aims at optimizing the transportation network, reducing thus the environmental impact.

- Model implemented in the General Algebraic Modeling System (GAMS). unknown; thus the stream of recycled products has not been accounted for.

- Final result is a compromise between environmental versus financial efficiency.

\section{PRoposed Model For MATChING SUPPLY AND DEMAND OF C\&DW}

\subsection{General Modelling Approach}

In order to efficiently manage the C\&DW waste chain, a multi-level facility location problem's structure is adopted. The value of this modelling approach is that it uses mathematical programming to select the set of facilities that minimizes the costs associated with all possible reverse flows. The options considered are sorting, recycling and safe disposal in engineered landfills. The model will not only account for existing facilities, but also for newly constructed ones in a way to satisfy projected waste supply. These new facilities will be located in abandoned quarries with suitable characteristics, thus minimizing the possibility of the "Not in My Back Yard" (nimby) syndrome.

Figure 2 illustrates a simplification of the network. On the regional scale, waste streams will depart from current and projected centroids of new construction and demolition sites to the closest processing facilities. Once separated and crushed, unrecyclable refuse will be disposed of in engineered inert landfills while recycled aggregates will be sent to suitable markets (concrete batch plants and existing quarries). Other materials such as metals, glass, etc. are not in the scope of this study, and are assumed to be disposed of in landfills.



Figure 2: Example of forward and reverse C\&DW flows

In consequence, the model's output consists of the selection of a subset of sites for material recovery and landfilling from a full set of sites and the number of processing modules so as to maximize profits. 


\subsection{Formal Model Formulation}

Available data is a key to every model formulation. For this problem, it is assumed that the locations of the centroids, the potential markets and the suitable candidate quarries are known. The shortest distances between these different facilities should be found. Additionally, the techniques adopted in the various facilities should be well defined in order to determine the capacity per module and the corresponding price. Last, the projected supply of C\&DW, the projected demand of recycled products and the areas of the quarries will be used to decide on the number of modules and thus are crucial to the model resolution. At this stage, a mixed-integer linear programming can be formulated.

\subsubsection{Objective function}

The objective function focuses on the multiple elements of cost with the goal of either minimizing total costs or maximizing profits. Since in developing countries, basic regulations for proper waste management are rare to non-existent, private investments are the origins of any sustainable initiatives. For this reason, the objective function adopted will focus on maximizing profits of the plants' owners, in opposition to the two models discussed previously where the sole beneficiaries were the recycled concrete plant owners.

By definition, the profit is the difference between what is earned and what is spent. Financial costs included are the construction and operational costs of the three types of facilities along with transportation costs of the refuse. Revenues earned result from selling recycled products and from processing fees. Furthermore, the environmental costs are accounted for in the transportation costs: the more optimal the network is, the less $\mathrm{CO} 2$ particles emitted. It is worth noting that not all abandoned quarries will be considered in the model. Quarries must be carefully screened for suitability in environmental and social factors such stability, settlement, hydrological conditions and impact on traffic. This step guarantees an environmentally appropriate location.

\subsubsection{Variables and Parameters}

Two types of variables are resorted to in this model. The first variable refers to the integer number of modules of a type of facility in a specific location. The second deals with the quantities of materials transported from one node to another. These can be C\&DW, sorted waste or landfilling materials.

For the model to function properly, several parameters must be valued. The quantities of C\&DW generated must be estimated with a suitable method as discussed previously. Approximations for the percentage of inert materials and the share of this percentage that can be recycled into fine versus coarse aggregates must be averaged from the literature. As for the quarries, the available area and exact location should be known. Similar information can be accessed through documentations from the appropriate authorities. In addition, for each facility, the module design and the choice of equipment must first be agreed upon. Afterwards, the capacity, the required area as well as the construction costs can be determined. Sorting and recycling prices per unit mass must then be set along with the transportation costs of a unit mass of material per $\mathrm{km}$ for the specific type of truck used. Finally, the selling price per unit mass of type of recycled products (coarse and fine aggregates) and the gate fees should be regulated in a way to attract buyers and contractors in a specific market. 


\subsubsection{Constraints}

The last step in every model formulation is defining the constraints. For this problem, mass balance for the system and at each node or facility must be verified. Capacity limitations on the different types of facilities must be ensured, and the market demand must be satisfied. Also, a constraint should be concerned with the quarry's area limitations. This parameter is essential for deciding on the number of modules of each type in every quarry.

\subsection{Advantages and Limitations}

The optimisation model discussed above acts as a decision support tool in the selection of appropriate set of quarries to serve as recovery facilities and landfills for C\&DW. This work accounts for the complete C\&DW management chain, rarely addressed in the literature. Moreover, it provides an environmental solution for underdeveloped countries whereby abandoned quarries will be correctly rehabilitated and made use of in the processing of C\&DW, a second problematic burden.

Like every modelling work, this model is subject to several assumptions and simplifications imposed by runtime requirements or lack of data. These include the recurrence to modular units to represent the new capacities added, limiting thus the technology considered and forcing a unique type of solution. In addition, only cementitious materials are processed in this model. Other materials such as metals, plastics, organics, etc. are only separated and disposed of. In real life, these are to be recycled and reused as well. Also, the mapping of the C\&DW supply origins into centroids considerably reduces the accuracy of the results obtained and excludes the possibility of using mobile plants. Furthermore, the supply and demand over the design period is subject itself to variations and errors due to surrounding circumstances such as technological breakthrough as well as economical and spatial developments.

\section{RESEARCH SUMMARY, FUTURE WORK AND LIMITATIONS}

This paper reviewed methods to quantify C\&DW as well as previous models employed to optimize the solid waste management chain. Further sections introduced the model to be formulated which will serve as a decision support in the selection of a cost and environmentally effective set of abandoned quarries to serve as C\&DW landfills and recycling facilities. Similarly to Hiete et al.'s work and in opposition to Galan et al.'s formulation, this model will account for both supply and demand of C\&DW. The model also aims at profit maximization since the lack of appropriate regulations in developing countries leads to a private financing of sustainable facilities.

Ongoing work includes a comprehensive formulation of the model according to the objective function and constraints already defined. The model will then be tested and validated through a case study of a developing country from the field.

\section{ACKNOWLEDGEMENTS}

This study was funded through a grant from the American University of Beirut University Research Board (Project No. 23284), Beirut, Lebanon. 


\section{REFERENCES}

Bakshan, A., Srour, I., Chehab, G. and El-Fadel, M. (2015). A field based methodology for estimating waste generation rates at various stages of construction projects. Resources, Conservation and Recycling, 100, pp.70-80.

Banias, G., Achillas, C., Vlachokostas, C., Moussiopoulos, N. and Tarsenis, S. (2010). Assessing multiple criteria for the optimal location of a construction and demolition waste management facility. Building and Environment, 45(10), pp.2317-2326.

BRE (United Kingdom Building Research Establishment), (2008). SMARTWaste System. Available at: http://www.smartwaste.co.uk/ [Accessed 10 Nov. 2016].

Clemen, R. (1996). Making hard decisions, an introduction to decision analysis, Second edition, Duxbury Press.

Deloitte \& Touche (M.E.), (2015). Construction - The economic barometer for the region. Deloitte GCC Powers of Construction. [online] p.10. Available at: https://www2.deloitte.com/xe/en/pages/real-estate/articles/gcc-powers-ofconstruction-2015.html [Accessed 14 Nov. 2016].

Eurostat, (2015). Energy, transport and environment indicators. Luxembourg: Publications Office of the European Union.

Fonseca, N., de Brito, J. and Evangelista, L. (2011). The influence of curing conditions on the mechanical performance of concrete made with recycled concrete waste. Cement and Concrete Composites, 33(6), pp.637-643.

Galan, B., Dosal, E., Andrés, A. and Viguri, J. (2013). Optimisation of the construction and demolition waste management facilities location in Cantabria (Spain) under economical and environmental criteria. Waste and Biomass Valorization, 4(4), pp.797-808.

Hiete, M., Stengel, J., Ludwig, J. and Schultmann, F. (2011). Matching construction and demolition waste supply to recycling demand: a regional management chain model. Building Research \& Information, 39(4), pp.333-351.

Hosseini, M., Rameezdeen, R., Chileshe, N. and Lehmann, S. (2015). Reverse logistics in the construction industry. Waste Management \& Research, 33(6), pp.499-514.

Knoeri, C., Sanyé-Mengual, E. and Althaus, H. (2013). Comparative LCA of recycled and conventional concrete for structural applications. The International Journal of Life Cycle Assessment, 18(5), pp.909-918.

Madi, N. (2016). A GIS-based framework for managing construction and demolition waste: The case of Syria. Graduate Student. American University of Beirut.

Malia, M., de Brito, J., Pinheiro, M. and Bravo, M. (2013). Construction and demolition waste indicators. Waste Management \& Research, 31(3), pp.241-255.

Martínez Lage, I., Martínez Abella, F., Herrero, C. and Ordóñez, J. (2010). Estimation of the annual production and composition of C\&D Debris in Galicia (Spain). Waste Management, 30(4), pp.636-645.

Ministry of Environment, (2011). State of the Environment Report in Lebanon. Beirut.

Noche, B., Chinakupt, T., Rhoma, F. and Jawale, M. (2010). Optimization Model for Solid Waste Management System Network Design Case Study. IEEE, 5, pp.230-236.

Najm, M., El-Fadel, M., Ayoub, G., El-Taha, M. and Al-Awar, F. (2002). An optimisation model for regional integrated solid waste management I. Model formulation. Waste Management \& Research, 20(1), pp.37-45.

Robinson, G. and Kapo, K. (2004). A GIS analysis of suitability for construction aggregate recycling sites using regional transportation network and population density features. Resources, Conservation and Recycling, 42(4), pp.351-365. 
Srour, I., Chehab, G., El-Fadel, M. and Tamraz, S. (2013). Pilot-based assessment of the economics of recycling construction demolition waste. Waste Management \& Research, 31(11), pp.1170-1179.

Xi, B., Su, J., Huang, G., Qin, X., Jiang, Y., Huo, S., Ji, D. and Yao, B. (2010). An integrated optimization approach and multi-criteria decision analysis for supporting the waste-management system of the City of Beijing, China. Engineering Applications of Artificial Intelligence, 23(4), pp.620-631. 